\title{
Tolerant Speech in Multicultural Community Communication
}

\author{
Arief Rijadi
}

\section{Universitas Jember}

Email: ariefrijadi.fkip@unej.ac.id

\begin{abstract}
Building awareness of a harmonious and peaceful life in a multicultural society requires tolerant attitudes. This tolerance is one of the values that have been upheld since the Enlightenment period in the mid-18th century with the emergence of the conception of humanism, renaissance, and reform, especially in England and France and "aufklarung" in Germany. This value of tolerance is seen as very important, so Enesco issued a Declaration of Tolerance Principles in 1995. Intolerance can arise from various aspects, including the use of language. The use of language that is not tolerant, both in structure and substance, can have an impact on the effectiveness of communication between speech participants. That is, in communication, the choice of language and variety of languages, as well as tolerant speech, becomes a demand based on social, psychological, and cultural rules. Therefore, this article aims to describe forms of tolerant speech in a multicultural society and tolerant speech styles in communication in a multicultural society. The study of tolerant speech in the communication of a multicultural society is carried out with a pragmatic approach through the ethnographic design of communication. The data are in the form of speech segments and their context in a speech event of multicultural community communication. Data analysis was carried out in an eclectic way through the stages of identification and classification, interpretation, pairing, and data meaning. The results of the analysis obtained are in the form of tolerant speech forms based on the pattern of language structure, the form of greeting, expression, use of modalities, and use of references. Meanwhile, the tolerant speech style found in the series of research includes phatic speech style, self-telling, joking, information dissemination, information decomposition, analogizing information, giving reasons, repetition, focusing, comparison, illustrating, detailing, strengthening.
\end{abstract}

Keywords: pragmatics, tolerance, tolerant speech, multicultural society, communication

\section{INTRODUCTION}

A society that has diversity in various aspects, such as in Indonesia, requires a special strategy to manage it. This needs to be done so that a peaceful and harmonious social life can be realized properly. For that, every member of the community needs to realize that coexistence with different backgrounds requires mutual respect, respect and tolerance. Such attitudes can be represented as intolerant utterances so that it is expected to avoid potential conflicts from various dimensions of life.

Tolerance is one of the value concepts that were upheld during the enlightenment period in addition to the value of truth and humanism (Hilman, Tjahjandari, and Untari, 2003:58). Tolerance which etymologically comes from the Latin toleraré is an attitude of respect, letting, and allowing in a relationship [1]; [2]. The spirit of tolerant life and the importance of this attitude of tolerance, UNESCO finally issued an important concept in a Declaration of Tolerance Principles in 1995 and declared on November 16, 1996, as the International Day of Tolerance. In the declaration, UNESCO (1996; Rijadi,[2]) defines tolerance as respect, acceptance and appreciation of the world's cultural diversity, forms of expression, and ways of being human.

Concerning tolerant speech, Rijadi [1]; [2] states that tolerance is an important concept that needs to be considered. Rijadi further stated that tolerant speech is a person's attitude in heeding the interests of others or considering other people's feelings towards their beliefs with language as the main instrument. This is in line with Aziz's [3] view that tolerance is an important aspect in realizing harmonious social communication. In speaking, according to Aziz [3]; Rijadi [4]), a speaker needs to consider the principle of mutual tolerance (PSTR). PSTR tries to integrate the occurrence of mutual understanding between speech participants in maintaining each other's feelings, so that social and cultural harmony will always be maintained [4]. For this 
tolerant speech, Rijadi [2] formulates the rules, namely (1) there is no coercion in the use of language rules between speeches participants, and (2) there is acceptance between speech participants against the limitations of the language competence used.

In a multicultural society, tolerant speech requires good communication skills for each member. This communication ability is not only limited to understanding the rules of the language but also understanding the different cultures between members of the community with different cultural backgrounds. By referring to the rules of tolerant speech, in the communication of a multicultural society, speech participants can use various forms of tolerant speech and speech styles. The following speech segments can illustrate how tolerant speech is.

\section{Speech Segment}

Lecture : Baik, saudara-saudara sekalian, pertemuan hari ini kita melanjutkan diskusi kelompok dengan tema Jenis-jenis Makna. Saya cek di WA grup maupun WA saya, bahan presentasi belum dikirim.

Student's : Sudah Bapak, tadi pagi ke WA sampean juga sudah.

Lecture : Oh begitu, ya nanti saya lihat. Silakan dimulai.

\section{Context}

This speech event occurred during a Semantic Indonesian lecture through a web meeting application. The lecturer explained the lecture activities at that time. In addition, he also asked why the group discussion presentation materials had not been sent to other lecturers and students.

The speech segment above contains greeting utterances that implement tolerant speech, namely the words spoken by the lecturers and the words spoken by students. The greetings of the lecturers represent tolerant speech because the social status of lecturers and students are equal. This statement shows that there has been a shift in social status. In academic culture, the lecturer's speech seems to appreciate the social status of students more. According to Sunoto [5], this shift shows respect or flattery to students which socially creates a dialogical relationship in diplomatic contacts. Judging from the purpose or intent, the speech includes declarative speech.

Then your speech also shows the implementation of the rules of language tolerance. Students use your speech intending to respect lecturers who socially have a higher social status. For people who understand the level of speech, your speech is not quite right in the speech segment. However, the lecturer has provided an excuse for the students' incomprehension in using the speech level. Lecturers can also follow up on their speech by explaining the rules for using your word following the rules of the language. This speech is also seen from the purpose or intent, the speech also includes declarative speech.

This research article also describes the tolerant speech style in communication in a multicultural society. Speech style in this study refers to the ways or strategies of speech participants. Tolerant speech style shows the efforts of speech participants in communicating which aims to maintain harmonious and acceptable relationships psychologically, socially and culturally. Thus, this article attempts to describe various forms of speech and tolerant speech styles in communication in a multicultural society.

\section{METHOD}

This research article uses a pragmatic approach. The pragmatic approach places speech acts as objects of linguistic study by linking the context of speech as the background of speech events. According to Levinson [6], pragmatics is the study of the relationship between language and the context encoded into the structure of language. The research design was carried out by following the way of communication ethnography. Whitney [7]) states that communication ethnography is used to reveal the structure of meaning in research settings, synthesize group realities that characterize and separate them, and present them externally to trigger deeper considerations. The stages of the design of this ethnographic communication research carried out by referring to the views of Kuswarno [8] include the identification of repeated communication events, an inventory of communication components in building communication events, and finding relationships between communication components that build communication events or patterns.

The data of this research are in the form of speech segments and their context in the learning process which is identified as having the implementation of language tolerance rules. The research data was obtained by participating and non-participating observation techniques. The stages of observation include the stages of recording, transcription, identification, and field placement. The selected data were analyzed eclectically through the stages of identification and classification, interpretation, pairing, and data meaning. This data analysis model is in line with the interactive model developed by Miles \& Huberman [9] through the steps of reducing data, presenting the results of data analysis, drawing conclusions and verifying data.

\section{RESULT AND DISCUSSION}

Based on the research objectives, the results of the analysis of research data are presented below, namely a description of tolerant speech forms and tolerant speech styles in multicultural community communication. 


\subsection{Forms of Tolerant Speech}

The results of a series of studies that have been carried out are obtained, descriptions of tolerant speech forms in multicultural community communication in various contexts of speech events. These tolerant speech forms can be classified based on the pattern of language structure, the form of greeting, expression, use of modalities, and use of references. The various forms of tolerant speech can be described as follows.

\subsubsection{Tolerant Speech Based on Language Structure Pattern}

The pattern of tolerant speech-language structure in multicultural society communication can be in the form of declarative, imperative, interrogative, and interjection speech. First, declarative tolerance speech is intended to tell something. Tolerant speech is generally in the form of statements that are notification, explanation, and affirmation. The declarative markers found in the research include good, yes, agree, and agree. Second, imperative tolerant speech is a language structure that contains the act of ordering the speech partner to do something according to the speaker's intention. The variety of imperative tolerant speech can be in the form of requests, expectations, requests, and suggestions. Imperative tolerant speech markers include come on, come on, the particle word "lah", please, beg, preferably, should. Third, interrogative tolerant speech aims to ask for a response from the hearer to something he wants to know. Interrogative speech is also used as an effort to evaluate the results of a job or project. In carrying out tolerance speech, it is better to avoid using questions that are thought to be unknown, answer their questions, use questions with simultaneous answers, appointing someone who must answer before asking a question. Fourth, speech tolerates interjection as speech that expresses the feelings of the speech participants. Interjection utterances can be in the form of admiration, sadness, surprise, anger, pain, and so on. According to Rijadi [1], Rijadi \& Hanief [10], interjection speech has a high level of feeling and is effective and is a speech participant.

\subsubsection{Tolerant Speech in the Form of Greetings and Greetings}

Greetings are grammatically in the form of words or phrases used by speech participants to greet each other. The use of greeting speech is an important aspect in realizing and fulfilling effective communication ethics. The greetings found in the communication of multicultural society are in the form of personal pronominal greetings, kinship greetings, friendship greetings. Greetings are usually found in starting and ending activities, such as the learning process, meetings. In implementing greetings speech, Rijadi's [1]. Rijadi \&
Hanief [10] need to consider two things, namely (1) use general greetings according to time, and (2) use greetings that do not offend others from the aspect of ethnicity, language, religion, race, and culture.

\subsubsection{Tolerance in the Form of Expressions}

Tolerant expressions found in a multicultural society communication are in the form of offerings and jokes. The expression of offering is something that is given to another party (partner of speech) who is respected or appreciated which is done specifically and for a special purpose as well. Furthermore, the joking expression is basically to make the atmosphere fun, fluid, and break the deadlock/freeze of communication.

\subsubsection{The Use of Modalities in Tolerant Speech}

Modalities are forms of language that describe a person's judgment based on the speaker's reasoning, taste, or desire for the perception of his soul. The modalities in tolerating speech acts can refer to four categories, namely intentional modalities, epistemic modalities, deontic modalities, and dynamic modalities. In this study, only three forms of tolerant speech modalities were found, namely intentional, epistemic, and deontic modalities.

\subsubsection{Use of References in Tolerant Speech}

A reference is a form of tolerant speech used by speech participants to strengthen their opinion. The forms of tolerant speech through the use of references found in this study are in the form of references to regulations or legislation, policy references, and religious references. Tolerant speech with the use of regulatory or statutory references is obtained from sources of applicable laws or regulations established by an institution. The use of policy references is based on a trait that always uses reason. Then, the use of religious references is intended to strengthen opinions based on the provisions of the religion they believe in, both their behaviour and actions are included in speaking.

\subsection{Tolerant Speech Style}

Based on the results of Rijadi's research [2], the speech style in this study refers to the way or style of speech participants in communicating who can maintain good relationships and are psychologically and socially acceptable. Tolerant speech style in multicultural society communication can be done with phatic speech style, self-telling, joking, information dissemination, information decomposition, analogizing information, giving reasons, repetition, focusing, comparison.

\subsubsection{Phatic Speech Style}

Phatic speech in a conversation is needed to break the silence or communication freeze. Phatic speech style 
is used by speech participants for conversational exchanges and not for what they are saying. In other words, phatic is used to build intimacy or keep the conversation process going well. Examples of phatic speech, Who do you want to meet? Would you like a consultation too? Who are you waiting for?

\subsubsection{Self-telling Speech Style}

The speech style of self-telling is a series of utterances containing the speaker's self-experience which is intended to explain his ideas, thoughts and experiences to the hearer. In the context of the conversation, self-telling is used for understanding problems and can be a model for problem-solving.

\subsubsection{Joking Speech Style}

The style of joking refers to speech that contains humour so that it makes the speech partner laugh, happy, happy, and happy. The joking style of speech is usually done by speakers to close social distance and even the social status of the speech partner. Therefore, joking in a conversation can make the interlocutor not awkward or embarrassed. Examples of joking speech styles such as, "You're a little backward huh. Well, so beautiful it looks perfect." or "Wow, this is making me short of breath. Why? Because half of my breath is in all of you."

\subsubsection{Information Dissemination Speech Style}

Information dissemination speech style is the style of speakers who use speech as it is or straightforward. Straightforward utterances are meaningful speech expressions according to their lexical meaning. Examples of information dissemination speech styles such as "Please pay attention, ladies and gentlemen. (still noisy). Once again, please pay attention. I ask you to calm down first. Let's listen to the explanation from the tax service office first."

\subsubsection{Information Decomposition Speech Style}

Information decomposition speech style is the style of a speaker in explaining a material or problem clearly and in detail. With this style of speech, the speaker provides information in a disorganized manner and is spoken as clearly as possible so that the speech partner understands the material or the problem he is facing. Sometimes for the speech partner to obtain clear information, the speaker can repeat the explanation of the material or problem he is talking about.

\subsubsection{Analogizing Information Speech Style}

Analogizing information speech style is the use of speech to provide information by using an analogy to two different things. This style of speech is spoken using figurative language. An example of this speech style, for example in research, an object needs to be compared with a different object. For example, "Wait a minute, what do you actually want to research? I'm not trying to follow you. Or like this, in researching it, let's say we're going to research CHAIRS. If we want to research the quality of chairs, we'll look at the materials used. Therefore, what we examine is the shape or design.".

\subsubsection{Giving Reasons Speech Style}

Giving reasons speech style is used by speech participants in realizing acts of language tolerance. This style of speech aims so that the speech partner can understand a problem. Usually, this style of speech is used if there is a misunderstanding of the substance of the conversation material. Giving inappropriate reasons can cause the communication process to not take place properly.

\subsubsection{Repetition Speech Style}

Repetition speech style is used by speech participants to build effective communication. Repetition speech style is used by speech participants to affirm their will on the object of the conversation they are doing. In particular, a repetition speech style is used to restore a good conversational atmosphere.

\subsubsection{Focusing Speech Style}

Focusing speech style is the style of the speech participant to emphasize, emphasize, or return the object of the speech event so that it does not extend to the subject matter discussed, returns attention, or something that can offend the speech participant. Focusing speech style is intended to maintain and control the atmosphere of speech events in a conducive atmosphere.

\subsubsection{Comparison Speech Style}

Comparison speech style is done by comparing one object with another object. Example of a Comparison speech style, "With CAR it will be easier, just smooth it out, compared to making a new one, think again ... he he he."

\section{CONCLUSION}

Based on the rules of language tolerance, a tolerant speech is a representation of the use of language by speech participants so that communication can take place effectively and create harmonious relationships between speech participants. The diversity of speech that appears to realize language tolerance can be seen from the various forms and speech styles of the participants. The forms of tolerant speech can be in the form of speech based on the pattern of language 
structure, the form of greeting, expression, use of modalities, and use of references. Meanwhile, the tolerant speech style found in the series of research includes phatic speech style, self-telling, joking, information dissemination, information decomposition, analogizing information, giving reasons, repetition, focusing, comparison, illustrating, detailing, strengthening.

\section{AUTHOR'S CONTRIBUTION}

In several linguistic studies that have been carried out, the author has contributed to the development of pragmatic principles or theories. This article is a pragmatic study that focuses on language ethics in a multicultural society. Language tolerance becomes something important in building character, especially in multicultural community interactions. Language tolerance also aims to build a harmonious and peaceful society, mutual respect and mutual respect for all forms of differences.

\section{ACKNOWLEDGMENT}

On this occasion, the authors would like to thank (1) DRPM Kemenristekdikti, (2) LP2M University of Jember, (3) Postgraduate State University of Malang, and the 2021 KIMLI Committee, MLI Center, and Branch of MLI Hasanudin University.

\section{REFERENCES}

[1] Rijadi, A. (2016a). Revitalisasi Tuturan Bertoleransi dalam Pembelajaran Bahasa Indonesia sebagai Pembentukan Karakter Peserta Didik. In the Proceedings of the National Seminar on the Role of Indonesian Language Learning in Improving the Intelligence of Logic, Ethics, and Aesthetics of Students. Malang: Postgraduate Indonesian Language Education Study Program, State University of Malang.

[2] Rijadi, A. (2016b). Toleransi Berbahasa dalam Komunikasi Forum Edukatif. The dissertation is not published. Malang: Postgraduate State University of Malang.

[3] Aziz, Endang Aminuddin. (2012). Merumuskan Prinsip Kesantunan Berbahasa dalam Masyarakat Indonesia. [Online]. http://aminudin.staf.upi.edu/2012/02/17/merumusk an-prinsip-kesantunan-berbahasa-dalammasyarakat-indonesia/. Downloaded 20/01/2013.

[4] Rijadi, A. (2016c). Toleransi Berbahasa dalam Wacana Interaksi Formal di Lingkungan Masyarakat Multietnik. Doctoral Dissertation
Research (PDD). Not Published. Jember: University of Jember.

[5] Sunoto. (2012). Masyarakat Jawa dalam Terawangan Serat Babad Kediri. Dissertation Unpublished. Malang: Postgraduate State University of Malang.

[6] Levinson, S.C. (1983). Pragmatics. London: Cambridge University Press

[7] Mudjiyanto, B. (2009). Metode Etnografi in Communication Research. Journal of Komunikasi Massa. Volume 5 Number 1, 2009. Pg. 79-87. Surakarta: Department of Communication, Faculty of Social and Political Sciences, Sebelas Maret University.

[8] Kuswarno, E. (2011). Etnografi Komunikasi, Pengantar dan Contoh Penelitiannya. Second printing. Bandung: Widya Padjajaran.

[9] Miles, M.B. \& Huberman, A.M.. (1992). Analisis Data Kualitatif. Jakarta: UIP.

[10] Rijadi, A. \& Hanief, L. (2017). Representasi Tindak Tutur Bertoleransi dalam Pembelajaran Karakter di Kelas Rendah pada Era Global. Proceedings of the National Seminar \#3 Indonesian Language and Literature in a Global Context. 22 March 2017, Jember, Indonesia. page. 415-428. https://jurnal.unej.ac.id/index.php/fkipepro/article/view/4913/3627 